\title{
Trend Analysis of Pakistan Railways Based on Industry Life Cycle Theory
}

\author{
Xuemei Li, ${ }^{1}$ Khalid Mehmood Alam $\mathbb{D}^{1},{ }^{1}$ and Shitong Wang ${ }^{1,2}$ \\ ${ }^{1}$ School of Economics and Management, Beijing Jiaotong University, Beijing 100044, China \\ ${ }^{2}$ School of Economics and Management, Tianjin Chengjian University, Tianjin 300384, China \\ Correspondence should be addressed to Khalid Mehmood Alam; 15119006@bjtu.edu.cn
}

Received 6 October 2017; Revised 7 February 2018; Accepted 18 March 2018; Published 24 April 2018

Academic Editor: Zhi-Chun Li

Copyright (c) 2018 Xuemei Li et al. This is an open access article distributed under the Creative Commons Attribution License, which permits unrestricted use, distribution, and reproduction in any medium, provided the original work is properly cited.

\begin{abstract}
The core purpose of this paper was to analyze the trend analysis of Pakistan railways from the year 1950 to 2015, using the principal component analysis method and industrial life cycle theory. Industrial life cycle theory, the development trend analysis of Pakistan railway industry, entails four stages: introduction, growth, maturity, and decline. The results indicated that railway industry in Pakistan was at its pinnacle in the middle of the seventies and thereafter the decline of railway industry was observed. The main reasons behind the decline were underinvestment, political interference, and the rise of the same-sector competitor, the National Logistics Cell (NLC). From the year 2011, it experienced an upward trend of combined utility curve and showed a new round of industry life cycle. To revive its previous glory, the current government has proposed a development document for Pakistan railways, Vision 2025. It is envisaged that railways share in transportation will be increased from current $4 \%$ to $20 \%$ by the year 2025 , which seems to be an onerous challenge for the organization.
\end{abstract}

\section{Introduction}

It can be undoubtedly asserted that the economic development of a country is mainly subjected to its efficient transport system. Logistics is one of the key inputs in the production process and adequate provision of logistics and transport infrastructure helps in increasing productivity and lowering the production overheads. In comparison to other modes of transport, rail transport is relatively reliable, safe, and fast. Railways consist of many parts and operations [1] and appropriate employment of this mode to its full potential can help to reduce the congestion and anomalies on the roads, safeguarding a further safer and flat traveling. Rail is a comfortable, environment-friendly, and cheapest mode of transportation in Pakistan [2], whereas the large volume of goods can be transported over long distances quickly with insignificant impact upon the environment. Rail is the most emissions-efficient major mode of transport, and electric trains powered by renewable energy can offer practically carbon-free journeys and transport [3].

In 1947, when Pakistan achieved independence, 8,122 kilometers of railway tracks were adopted. Pakistan Railways is a public-sector organization, earlier known as the Pakistan Western Railway (1947 to 1974). From 1948, usage of railways increased and the network became profitable. From the year 1950 to 1955, it improved its operations by connecting West and East Pakistan (now Bangladesh). Railways used to be the predominant mode of transport in Pakistan, which, at its peak in the 1950s and $60 \mathrm{~s}$, handled $73 \%$ of the freight traffic, compared to less than $4 \%$ by the year 2011. During the 1970s, Pakistan Railways also had the largest passenger carrier share in transportation. Over the years, it has been criticized for its deteriorating quality of services and fading number of passengers, freight, and trains. Unfortunately, its role as a catalyst for economic development has received a setback due to significant underinvestment by successive governments who preferred investment in road infrastructure at the cost of railways. In the late 1980s and early 1990s, Pakistan Railways shut its numerous branch lines and minor stations due to declining passenger numbers and financial sufferings. To enhance the number of passengers and freight volume, Pakistan Railways had to make technological innovations, improve the quality of services, and control mismanagements. 


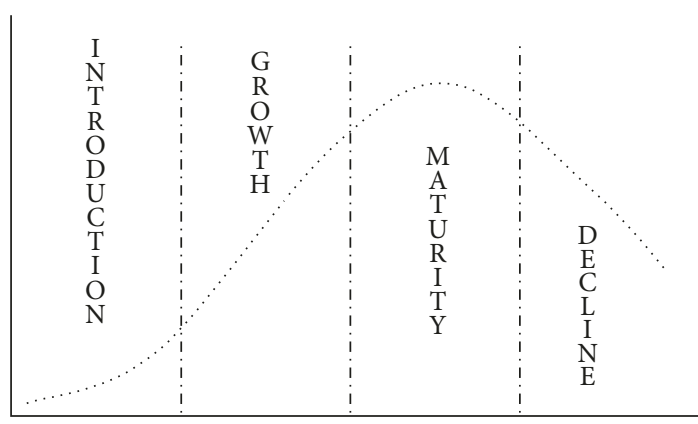

FIGURE 1: Industry life cycle curve.

\section{Concept of Industry Life Cycle}

An industry life cycle analysis allows for firms within the industry to frame policies [4] and nature of an industry changes as the industry moves through its life cycle [5]. The main views of how firms and industries progress are as follows: as some businesses mature and the source of competition shifts from product innovation to process innovation [6-9]. The idea of industry life cycle was presented by Michael in 1980 [10] and, according to this concept, the industry is the most important part of a firm. The concept of Porter (1980) is continued to explain certain behaviors of stages of industry life cycle with Abernathy/Utterback model [11]. It distinguishes life cycle of an industry with respect to the degree of dynamics of development of process and product innovations. The criteria for differentiating changes of individual stages are an increase or decrease in product and innovation process. The dynamics of development of the industry are defined by two types of threats: obsolescence threat to main events and threat to main assets [12]. The threat to main events refers to a major threat to industrial activities that have realized profits for the industry in the past. The threat to main assets is a threat to resources, knowledge, and brand which made the organization distinctive in the market. More generally, a firm's expertise and its ability to feat opportunities determine the organizational form [13-15].

2.1. Different Phases of Industry Life Cycle. The basic idea of life cycle theory comes from biology parallel with the life cycle of an organism [16]. According to industry life cycle, all industries go through four different phases, where each particular phase requires a policy that will effectively absorb the specific situations of the phase [17]. Industrial life cycle curve can usually be a sales revenue on the vertical axis and time on the horizontal axis represents S-shaped curve shown in Figure 1. It is generally divided into four stages, introduction, growth, maturity, and decline [16], and the industry life cycle analysis allows the management to adjust the business according to the needs of industry [18-20].

2.1.1. Introduction Stage. Evolving industries are new and product appears on the market in the introduction stage.
There is small market demand and customers are not aware of its potential benefits, so advertising is usually necessary and investments are needed to build upmarket. The basic distinctive of this phase of the life cycle is that there are no rules. The main reward is the biggest market share for those who are entering the market first [21]. Numerous advantages can be achieved in several ways, by designing a new product, using advanced business processes, and entering new markets. Over time, as new firms enter the market, the initial reward is reduced, compelling pioneers to take actions to raise or defend their market share. Pioneers reward depends on benefit from the difference between the cost of innovation and artificial costs, cost saving, mistakes of pioneers, and benefit from economies of scale [22]. There are two options to be a pioneer or to be a follower. Followers also have to decide whether to be early or late entrants and all options have benefits and drawbacks [23]. The followers may slightly be better than pioneers but, logically, the conclusion should depend on the specific features of each new market [24].

2.1.2. Growth Stage. In growth stage, the product has been successful and there is rapid spread of awareness and use of the product. With the development of new technologies, the unit cost is reduced, quality is improved, and demand is increasing, in addition to growth in profits. Most of the firms are planning their business not only by taking into account profit and sales but also by keeping the market share in mind, which is regarded as key to long-run profitability. However, the firm's goal should be not only to maximize the market share but also to achieve optimum market share [25]. Once the firm determines its optimal market share to achieve the market leader position, the firm should increase the overall market demand, defend its current market share, and try to increase market share.

2.1.3. Maturity Stage. In the maturity stage, the market share reaches a certain level but, at the same time, market demand is relatively slow and stable and industry is in recession. This transition from a phase of growth to maturity is an almost critical period for firms in the industry. This is the period during which fundamental changes are taking place in the company and are induced and also followed by a number of trends.

2.1.4. Decline Stage. Decline phase is characterized by falling profit margins, reduction in production, lower investment, and fewer competitors. In this phase of the industry life cycle, the strategic choice is the harvesting strategy as a strategic management decision to reduce investment in the business with the hope of reducing costs or improving cash flow. Customers have been attracted to other products, due to the fact that products and services cannot meet the market demand or lower prices of alternative products, making profit margins decline and outputs start to decrease and industry will enter the decline stage of the industry life cycle.

However, if the industry after recession comes through certain industrial innovations and upgradations, the output 


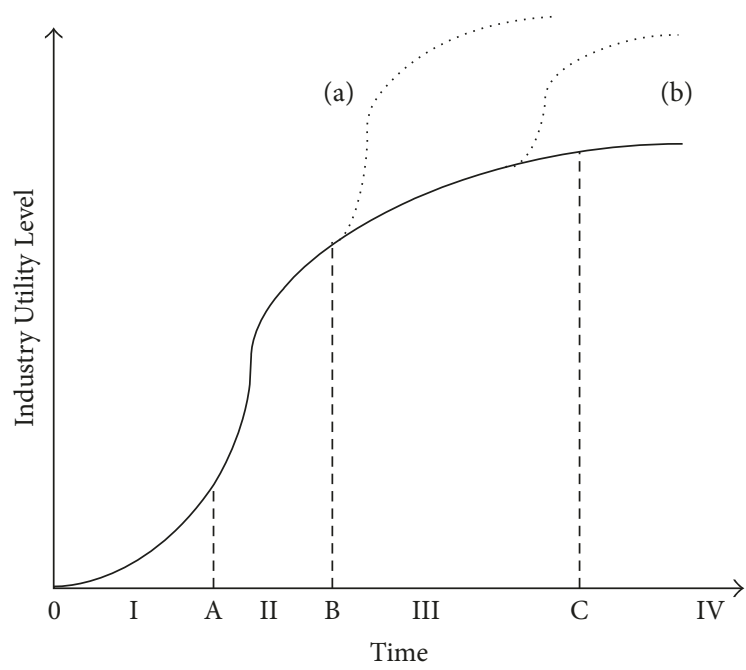

FIGURE 2: Industry life cycle with innovation.

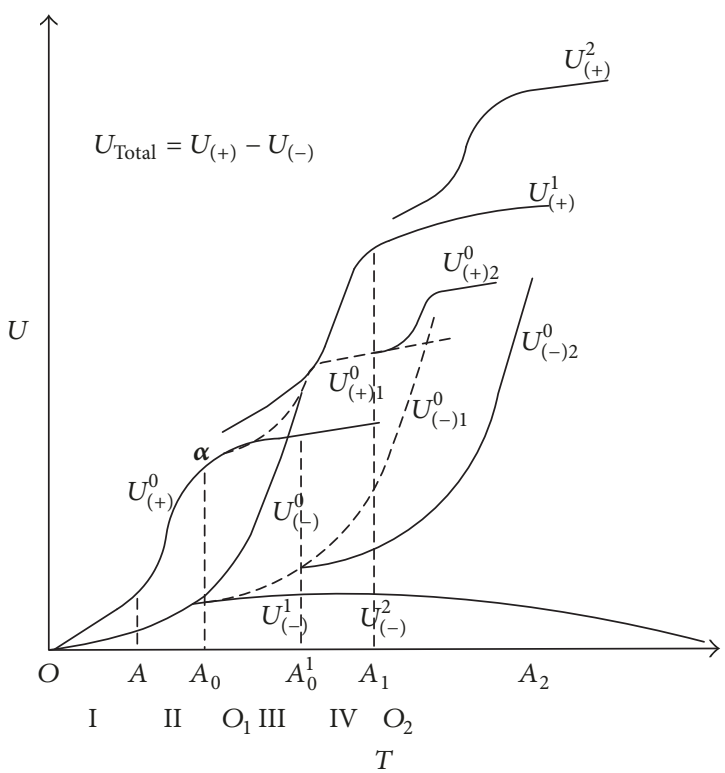

FIGURE 3: Long-term development trend of railway industry.

of the industry will stop to decline and may revive the industry and may bring a new round of industry life cycle [26]. Few industries will survive at the initial stage of maturity, while some industries survive at the end of maturity stage with the adaptation of advanced technologies, modernization of equipment, and management and service innovation as shown by dotted lines (a) and (b) in Figure 2.

\subsection{Long-Term Development Trend of Railway Industry Based} on Industrial Life Cycle Theory. In the long run, the sustainable development of railway industry is achieved by technological advancement and industrial modernization and advancement through management innovation, improvement in the quality of service, and adjustment according to market needs. The different approaches to decision-making may have different effects on firm performance. A response to opportunities is an appropriate way for firms in growth stage industries, where conditions are rapidly changing and opportunities for development are abundant. However, such environments may not favour the kind of typical competitive aggressiveness [27].

The marginal value of output is positive in the introduction, growth, and maturity periods of the industry and has a positive impact on the society, and marginal output of industry is significantly reduced or is even zero when the industry is in recession at the end of maturity period, indicating that the industrial development potential has been obviously insufficient and needs to take urgent countermeasures to achieve industrial improvement. When the industry enters the recession period, the marginal output of the industry is reduced sharply or is even negative, indicating that the contribution of the industry to the society cannot offset its negative effect on the society and the positive effects during the early stages of industry life cycle are replaced by the negative effect in the latter stages of industry life cycle [28]. If there are no effective industrial upgradation measures, the industry should shut down immediately.
The ideal long-term development trend of the railway industry is shown in Figure 3.

Following the theory of industrial life cycle, the function of measuring the output value of the railway can be expressed as the marginal utility of industrial development.

$$
U_{\text {Total }}=U_{(+)}-U_{(-)},
$$

where $U_{\text {Total }}$ is marginal revenue for output, $U_{(+)}$is marginal positive utility for the level of industrial development, and $U_{(-)}$is marginal disutility for the level of industrial development. $T$ is for time, $A, A_{0}$, and $A_{0}^{1}$ are demarcation points for introduction, growth, and maturity stages, respectively, $O_{i}$ is for a new round of industrial innovation and upgradation point $(i=1,2, \ldots), A_{j}$ is beginning point of industrial innovation and upgradation $(j=0,1,2, \ldots), U_{(+)}^{n}$ is change in marginal utility of railway industry for the gradual introduction of new technologies and management innovations $(n=$ $1,2, \ldots), U_{(-)}^{m}$ is change in marginal disutility for the gradual adoption of new technologies and management innovations $(m=1,2, \ldots)$, and $\boldsymbol{\alpha}$ identifies the time to adjust the industry.

In order to avoid the railway industry into the recession, the railway should determine $\boldsymbol{\alpha}$ even earlier in a maturity period, start to take scientific and technological progress, and improve the speed, service improvement, industrial upgradation, corporate restructuring, market expansion, and other revolutionary measures to improve industrial output and social impact. So, the utility curve $U_{(+)}$along the new curve $U_{(+)}^{1}$ entered a new round of industrial life cycle. The growth trend of $U_{(+)}^{1}$ is similar to $U_{(+)}$, the first (I) stage will experience slow growth, the second (II) stage will grow rapidly, the third (III) stage has steady growth, and the fourth (IV) stage has gradual decay. It still needs to 
discover transition point that can make the industry growth. Similarly, it is also important to reduce the negative effects $U_{(-)}$on output to achieve growth. The negative impact of the railway industry on the level of social development can be reduced by reducing internal costs, reduction in consumption of energy, improving internal organization and management. The positive impact of railway industry can be assumed from the positive growth, while the negative social impact continued downward deflection of the long-term level of development trend curve.

\section{Trend Analysis}

Pakistan Railways started its operations with 8,122 kilometers of railway tracks in the year 1947 [29]. At the initial stage, the overall capacity of railways was limited to provide a better transport facility to the customers. From 1948, railway industry improved its service quality, people used to travel with railways, and usage of railways increased. Data related to railway industry was available from the year 1950 to 2015; therefore the year 1950 was used as starting or base point to examine and study the development trends. For this paper, data were collected from Pakistan Railway Year Book 201415 and SPSS software was used for statistical analysis. At the initial stage, seven indicators, passenger volume, average passenger mileage, passenger turnover, freight volume, average freight mileage, freight turnover, and number of employed persons, were included for the analysis.

3.1. Principal Component Analysis. The central idea of principal component analysis (PCA) is to reduce the dimensionality of a data set consisting of a large number of interrelated variables, while retaining as much as possible the variation present in the data set [30]. PCA aims to detect the correlation between variables. If a strong correlation between variables exists, the attempt to reduce the dimensionality only makes sense [31]. In this paper, the variables are interrelated. The correlation coefficients are presented in Table 1.

Commonly used rotation methods are orthogonal rotation and oblique rotation. Orthogonal rotation method assumes that the factors in the analysis are uncorrelated, while oblique rotation method assumes that the factors are correlated. According to [32], varimax, quartimax, and equimax are orthogonal rotation methods and direct oblimin and promax are oblique rotation methods. To explore the rotation of components, varimax and quartimax of orthogonal rotation method and oblimin of oblique rotation method are employed. Table 2 represents the rotation of components and results appear to make very little difference.

3.2. Determination of Comprehensive Utility Factors. The comprehensive utility factor can reflect the overall utility of the railway industry development level. The contribution rate of the common factor indicates that the common factor reflects the amount of information of the original index, and the cumulative contribution rate represents the amount of information in which the corresponding common factors
TABLE 1: Correlation coefficients.

\begin{tabular}{cccccccc}
\hline & $X_{1}$ & $X_{2}$ & $X_{3}$ & $X_{4}$ & $X_{5}$ & $X_{6}$ & $X_{7}$ \\
\hline$X_{1}$ & 1 & & & & & & \\
$X_{2}$ & $-.873^{* *}$ & 1 & & & & & \\
$X_{3}$ & $.411^{*}$ & -.018 & 1 & & & & \\
$X_{4}$ & $.931^{* *}$ & $-.918^{* *}$ & .256 & 1 & & & \\
$X_{5}$ & -.174 & $.415^{*}$ & $.596^{* *}$ & -.185 & 1 & & \\
$X_{6}$ & $.944^{* *}$ & $-.855^{* *}$ & .312 & $.970^{* *}$ & -.196 & 1 & \\
$X_{7}$ & $.832^{* *}$ & $-.855^{* *}$ & .113 & $.885^{* *}$ & -.357 & $.918^{* *}$ & 1 \\
\hline
\end{tabular}

${ }^{*}$ Correlation is significant at the 0.05 level (2-tailed). ${ }^{* *}$ Correlation is significant at the 0.01 level (2-tailed). $X_{1}$ is number of passengers carried; $X_{2}$ is average number of kilometers travelled by passengers; $X_{3}$ is passenger turnover; $X_{4}$ is total freight carried; $X_{5}$ is average kilometers travelled by tonne; $X_{6}$ is freight turnover; $X_{7}$ is number of employed persons.

reflect the original index. The principal component analysis is used to identify the patterns in data [33] and to calculate the eigenvalues and contribution rates of the common factors of the seven variables are shown in Table 3.

Many methods have been proposed to determine the number of components to retain. The complication of the methods is diverse; some use simple graphs, while others are computationally demanding. These methods include scree plot and cumulative percentage of total variance. The traditional approach is to use the first few principal components in data analysis, since they capture most of the variation in the original data set. It has been suggested that $[34,35]$ one can use enough components to include most of the variation in the data.

The number of components to keep was based on the Kaiser criterion, for which only the principal components with the total variance greater than $85 \%$ were considered important [36]. On the basis of cumulative variance $>85 \%$, factor analysis developed first two factors explaining about $92.36 \%$ of the total variance (Table 3 ). Therefore, the seven indicators shown in Table 3 can be integrated into the first two main factors and can be factor load matrix. The first factor quantifies the maximum possible variation among different indicators and explains the largest proportion (67.620\%) of the total variance and the second factor explains a significant proportion $(24.120 \%)$ of the total variance.

A scree plot in Figure 4 displays the eigenvalues associated with a component or factor in descending order versus the number of the components or factors. This scree plot shows that two of those factors explain most of the variability because the line starts to straighten after the second factor. The remaining factors explain a very small proportion of the variability and are likely insignificant.

Commonality in principal component analysis is equal to the sum of all the squared factor loadings for all the factors related to the observed variable and this value is the same as $R^{2}$ in multiple regression [37]. The value ranges from zero to one, where one indicates that the variable can be fully defined by the factors and has no uniqueness. In contrast, a value of zero indicates that the variable cannot be predicted at all from any of the factors. In order to analyze the importance of included indicators in the development of 
TABLE 2: Rotation of components.

\begin{tabular}{|c|c|c|c|c|c|c|}
\hline \multirow{2}{*}{ Variables/components } & \multicolumn{2}{|c|}{ Varimax rotation components } & \multicolumn{2}{|c|}{ Oblimin rotation components } & \multicolumn{2}{|c|}{ Quartimax rotation components } \\
\hline & 1 & 2 & 1 & 2 & 1 & 2 \\
\hline$X_{1}$ & .963 & .151 & .964 & .163 & .961 & .160 \\
\hline$X_{2}$ & -.933 & .220 & -.931 & .208 & -.935 & .212 \\
\hline$X_{3}$ & .260 & .904 & .266 & .907 & .251 & .906 \\
\hline$X_{4}$ & .979 & .050 & .979 & .063 & .978 & .059 \\
\hline$X_{5}$ & -.280 & .880 & -.274 & .877 & -.288 & .878 \\
\hline$X_{6}$ & .979 & .082 & .980 & .095 & .979 & .091 \\
\hline$X_{7}$ & .934 & -.133 & .933 & -.121 & .935 & -.125 \\
\hline
\end{tabular}

TABLE 3: Principal component analysis explains total variance.

\begin{tabular}{lccc}
\hline Component & $\begin{array}{c}\text { Initial } \\
\text { eigenvalues }\end{array}$ & $\begin{array}{c}\text { Total \% of } \\
\text { variance }\end{array}$ & Cumulative \% \\
\hline 1 & 4.733 & 67.620 & 67.620 \\
2 & 1.688 & 24.120 & 91.740 \\
3 & .297 & 4.244 & 95.984 \\
4 & .172 & 2.460 & 98.444 \\
5 & .068 & .978 & 99.422 \\
6 & .037 & .523 & 99.945 \\
7 & .004 & .055 & 100.000 \\
\hline
\end{tabular}

TABLE 4: Communality of indicators.

\begin{tabular}{lc}
\hline Variable & Extraction \\
\hline Passenger volume & 0.950 \\
Average passenger mileage & 0.919 \\
Passenger turnover & 0.884 \\
Freight volume & 0.960 \\
Average freight mileage & 0.853 \\
Freight turnover & 0.966 \\
Number of employed persons & 0.890 \\
\hline
\end{tabular}

railway industry, principal component analysis was used to get the communality values (Table 4 ). The communality value of all the seven indicators, passenger volume, average passenger mileage, passenger turnover, freight volume, average freight mileage, freight turnover, and number of employed persons, was above $80 \%$, and it indicates that all the seven indicators have greater impact in the development of railway industry.

Rotated component matrix was obtained through principal component analysis to achieve the purpose of simplifying the structure so that each variable has a high load on a single factor and only a small to medium load on the rest of the factor. The most commonly used rotation method was the variance of the maximum orthogonal rotation method. Table 5 shows that freight turnover, freight volume, passenger volume, average passenger mileage, and number of employed persons load heavily on the first factor and the other two variables, passenger turnover and average freight mileage, load on the second factor.
TABLE 5: Rotated component matrix.

\begin{tabular}{lcc}
\hline \multirow{2}{*}{ Variables } & \multicolumn{2}{c}{ Components } \\
& 1 & 2 \\
\hline Freight turnover & 0.979 & 0.082 \\
Freight volume & 0.979 & 0.050 \\
Passenger volume & 0.963 & 0.151 \\
Average passenger mileage & 0.934 & -0.133 \\
Number of employed persons & -0.933 & 0.220 \\
Passenger turnover & 0.260 & 0.904 \\
Average freight mileage & -0.280 & 0.880 \\
\hline
\end{tabular}

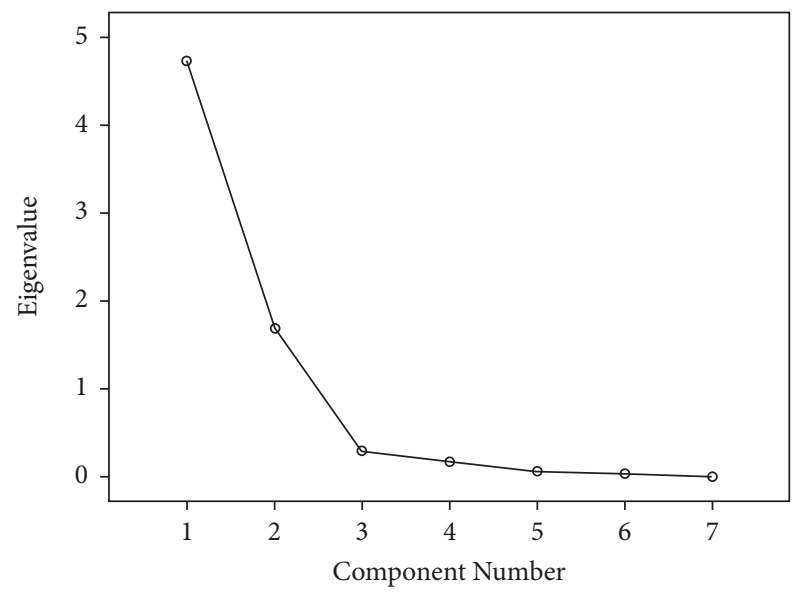

FIGURE 4: Scree plot of industry life cycle of railways.

The expression of the annual utility factor can be obtained:

$$
\begin{aligned}
Y_{1}= & 0.979 X_{1}+0.979 X_{2}+0.963 X_{3}+0.934 X_{4} \\
& -0.933 X_{5}+0.26 X_{6}-0.28 X_{7}, \\
Y_{2}= & 0.082 X_{1}+0.05 X_{2}+0.151 X_{3}-0.133 X_{4} \\
& +0.22 X_{5}+0.904 X_{6}+0.88 X_{7}, \\
Y= & 0.6762 Y_{1}+0.2412 Y_{2},
\end{aligned}
$$

where $X_{1}, X_{2}, \ldots, X_{7}$ are freight turnover, freight volume, passenger volume, average passenger mileage, number of employed persons, passenger turnover, and average freight 
mileage, respectively, and $Y$ value represents the annual level of development of railway industry.

3.3. Evaluation of Factor Scores. In order to evaluate the indexes, the factor scores are calculated for the two principal factors, and the factor scores are obtained, and the linearly weighted average sum is obtained with the respective contribution rate as the weight. The comprehensive scores of $Y, Y_{1}$, and $Y_{2}$ are obtained as shown in Table 6.

In order to better analyze the development trend of the railway industry, the time series regression analysis method was used for forecast. The number of time periods is represented by $t$, where $t=1,2, \ldots, 29$. The first time period represents the years 1950-55 and the last time period represents the years 2014-15.

In order to better predict the development trend of the railway, the paper uses the time series regression to fit the railway comprehensive utility level curve from the year 1950 to 1999 and from 1999 to 2015 to the corresponding utility development level curves $Y_{1}$ and $Y_{2} . Y_{1}$ represents the time period from year 1950 to 1999 and $Y_{2}$ represents the period from 1999 to 2015 and the result of time series regression analysis is represented in Tables 7 and 8 . The results are as follows:

$$
\begin{aligned}
& Y_{1}=-0.2514328+0.1282887 t-0.0027294 t^{2}, \\
& Y_{2}=6546-464.1 t-12.29 t^{2}+-0.1441 t^{3}-0.0006306 t^{4}, \\
& \widehat{Y}= \begin{cases}-0.2514328+0.1282887 t-0.0027294 t^{2} & t \in(1950,1999) \\
6546-464.1 t+12.29 t^{2}-0.1441 t^{3}+0.0006306 t^{4} & t \in(2000,2015) .\end{cases}
\end{aligned}
$$

Seven variables, passenger volume, average passenger mileage, passenger turnover, freight volume, average freight mileage, freight turnover, and number of employed persons, were used for factor analysis to calculate the comprehensive utility curve of Pakistan railway industry over the years from the year 1950 to 2015, as shown in Figure 5. $Y_{1}$ represents the time period from year 1950 to $1999, Y_{2}$ represents the period from 1999 to 2015, and $Y$ represents the comprehensive utility curve of the railway using the factor analysis. It can be seen from Figure 5 that the comprehensive utility level of the Pakistan railways reached its peak in 1975, and the development of the railway after 1975 showed a downward trend until the lowest level in 1999.

3.4. Industrial Life Cycle Analysis of Pakistan Railway Industry. The railway development stage is divided into the following stages:

1st Stage. From the year 1950 to 1975, the level of railway development is on the rise.

2nd Stage. From the year 1975 to 1999 , the level of railway development showed a downward trend.

3rd Stage. From the year 1999 to 2005, the level of railway development is on the rise and started a new round of railway industry life cycle, but the pace of development is slow.

4th Stage. From the year 2005 to 2011, the level of railway development was experiencing a downward trend.

Final Stage. From the year 2011 to 2015, the level of railway development has increasing trend and started a new second round of railway industry life cycle.

\section{Detailed Trend Analysis}

Pakistan railways experienced introduction, growth, maturity, and decline stage and a new round of industry life cycle over the years. The detailed trend analysis is as follows.

4.1. First Round of Industrial Life Cycle (1950-1999). The figure represents that Pakistan railways experienced the first round of industrial life cycle from the year 1950 to 1999 and completed four stages of introduction, growth, maturity, and decline. Detailed analysis of first round is as follows.

4.1.1. Start of Railway Industry (1947-1955). Railway services started with an adaptation of 8122 kilometers of railway tracks when Pakistan achieved its independence in the year 1947. This was the beginning of the Pakistan railway industry; its prominent feature was the lack of railway infrastructure, most needed to be reconstructed and repaired, but the rail transport has greatly improved over the years. After independence, Government of Pakistan invested huge amount for the development of railways. At the initial stage, railways were the only transport mode to connect the main cities and were used for passenger and freight transportation. In 1950s, railways industry increased its connectivity by extension of railways lines to other cities and started to provide better facilities by conversion of railway tracks from meter gauge to broad gauge. In 1954, the railway line was extended to Mardan and Charsadda (cities towards the northwest of the country), and in 1956 the Jacobabad-Kashmore (in the south) line was converted to broad gauge from meter gauge [29].

4.1.2. Growth and Maturity of Pakistan Railways (1955-1975). The rail industry has made considerable progress in expanding railway network and improved the quality of service to passengers and freight by new equipment and technology, management innovation, and increase in transport capacity. The overall level of effectiveness of railways industry has entered a rapid growth stage by an increase in passengers and freight carried. Because of the geographical shape of the country with a length of more than $2000 \mathrm{~km}$ from one 
TABLE 6: Factor scores.

\begin{tabular}{|c|c|c|c|}
\hline Years & Factor $1\left(Y_{1}\right)$ & Factor $2\left(Y_{2}\right)$ & Factors $(Y)$ \\
\hline 1950-55, average & 0.408 & -1.970 & -0.199 \\
\hline 1955-60, average & 1.024 & -1.546 & 0.320 \\
\hline 1960-65, average & 1.756 & -0.868 & 0.978 \\
\hline 1965-70, average & 1.987 & -0.633 & 1.191 \\
\hline 1970-75, average & 1.799 & -0.234 & 1.159 \\
\hline 1975-80, average & 2.098 & 0.779 & 1.606 \\
\hline 1980-85, average & 1.308 & 0.468 & 0.997 \\
\hline 1985-90, average & 0.911 & 0.123 & 0.645 \\
\hline 1990-95, average & 0.158 & -0.147 & 0.071 \\
\hline $1995-96$ & -0.263 & -0.123 & -0.208 \\
\hline 1996-97 & -0.381 & -0.175 & -0.300 \\
\hline 1997-98 & -0.448 & -0.220 & -0.355 \\
\hline 1998-99 & -0.490 & -0.122 & -0.361 \\
\hline 1999-00 & -0.382 & 0.072 & -0.241 \\
\hline $2000-01$ & -0.473 & 0.248 & -0.260 \\
\hline 2001-02 & -0.384 & 0.490 & -0.142 \\
\hline $2002-03$ & -0.295 & 0.622 & -0.049 \\
\hline 2003-04 & -0.276 & 0.834 & 0.015 \\
\hline 2004-05 & -0.304 & 1.719 & 0.209 \\
\hline $2005-06$ & -0.204 & 1.461 & 0.214 \\
\hline $2006-07$ & -0.150 & 1.207 & 0.189 \\
\hline 2007-08 & -0.171 & 1.359 & 0.212 \\
\hline 2008-09 & -0.425 & 0.831 & -0.087 \\
\hline $2009-10$ & -0.850 & -0.259 & -0.637 \\
\hline 2010-01 & -1.236 & -2.234 & -1.374 \\
\hline 2011-02 & -1.318 & -1.780 & -1.320 \\
\hline $2012-13$ & -1.226 & -0.707 & -0.999 \\
\hline 2013-14 & -1.120 & 0.287 & -0.688 \\
\hline 2014-15 & -1.051 & 0.518 & -0.586 \\
\hline
\end{tabular}

TABLE 7: Time series regression analysis for 1950-1999.

\begin{tabular}{lccc}
\hline Coefficients & Estimate & Std. error & $T$ value \\
\hline Intercept & -0.2514328 & 0.1717710 & -1.464 \\
Year & $0.1282887^{* * *}$ & 0.0154574 & 8.299 \\
Year $^{2}$ & $-0.0027294^{* * *}$ & 0.0002836 & -9.625 \\
\hline
\end{tabular}

$* * *, * *$, and $*$ indicate $1 \%, 5 \%$, and $10 \%$ significance level, respectively; $Y_{1}=-0.2514328+0.1282887 t-0.0027294 t^{2} ; R^{2}=0.9254$.

corner to another, Pakistan railways was considered to be an excellent, efficient, and cost-effective means for transporting goods and services from Karachi (south) to Peshawar (northwest). The Kot Addu-Kashmore line was completed in 1973, providing an alternative route from Karachi to upcountry, along with a right bank of Indus River [29]. During the 1970s, Pakistan railways also had the largest passenger carrier share in transportation. This was the golden period of Pakistan railways as its efficiency was at highest level. Railways used to be the predominant mode of transportation in Pakistan, which, at its peak in the 1950 s and 60 s, handled $73 \%$ of the freight traffic, compared to less than $4 \%$ by 2011 [38].
TABLE 8: Time series regression analysis for 1999-2015.

\begin{tabular}{lccc}
\hline Coefficients & Estimate & Std. error & $T$ value \\
\hline Intercept & $6546^{* *}$ & 1579 & 4.147 \\
Year & $-464.1^{* *}$ & 109.7 & -4.229 \\
Year $^{2}$ & $12.29^{* *}$ & 2.853 & 4.307 \\
Year $^{3}$ & $-0.1441^{* * *}$ & 0.03288 & -4.381 \\
Year $^{4}$ & $0.0006306^{* * *}$ & 0.0001417 & 4.450 \\
\hline
\end{tabular}

$* * *, * *$, and $*$ indicate $1 \%, 5 \%$, and $10 \%$ significance level, respectively; $Y_{2}=6546-464.1 t-12.29 t^{2}+-0.1441 t^{3}-0.0006306 t^{4} ; R^{2}=0.8631$.

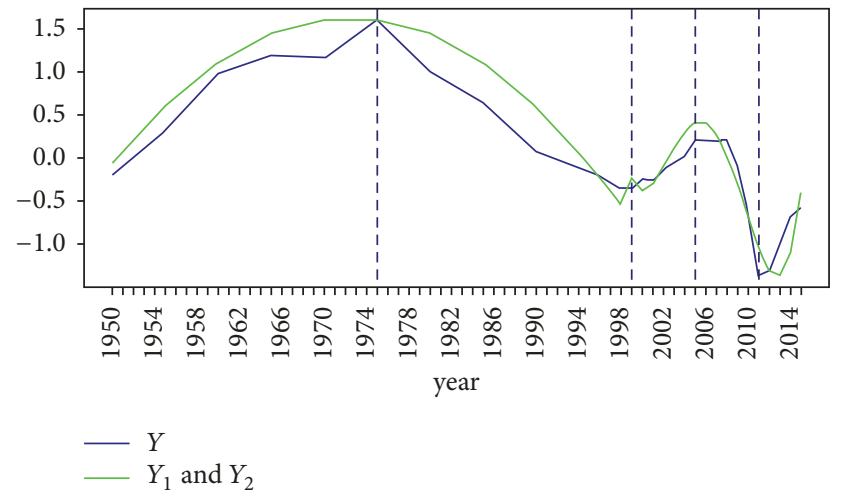

Figure 5: Trend analysis of Pakistan's railway industry from 1950 to 2014.

4.1.3. Decline of Railway Industry (1975-1999). Once considered to be the largest and most efficient transit system of freight (Magazines \& Review, 2011), railway industry after the year 1975 had a decline in the level of railway development because its share in passenger and freight carried started to decay and was at bottom level by the year 1999 .

(1) Under Investment and Political Interference. Railways role as a catalyst for economic development, in Pakistan, has received a setback due to significant underinvestment by successive governments that preferred investment in road infrastructure at the cost of railways. Apart from low investment in the railway industry, it also suffered from various issues that may have contributed to its decline. Some of the more projecting factors are political interference, poor human resource, decrepit infrastructure, and inability to develop a strategic business plan. Political intrusion in the recruitment process, nepotism, and poor human resource management have also backed a great deal in its decline. Posting and transfers on personal pleas or on political basis have caused a sense of job insecurity among the officers and thereby seriously affected the efficiency of the organization. Additionally, frequent changes in the appointment of senior officials have deteriorated the issue of long-term planning and its implementation.

(2) Establishment of National Logistic Cell (NLC). The main reason behind the decline of Pakistan Railways is the rise of National Logistics Cell (NLC), another competitor in the market. In 1978, National Logistics Cell was established as state organization to provide logistics management services 
and logistics protection and to reduce congestion at Karachi seaport. NLC successfully accomplished the task but Pakistan Railways was the biggest sufferer. It lost not only the advantage enjoyed in moving public sector freight but also the logistic business contracts of the Pakistan army. According to statistics released by Pakistan Railways, the number of freight wagons loaded was 680,696 by the years $1975-80$, which was decreased to 325,308 by the years $2005-10$. In the same period, the number of freight wagons owned by Pakistan Railways crashed from 36,515 to 18,569 . Road transport now carries $96 \%$ of the inland freight. Having the country's largest fleet of dry and liquid cargo freight service, the share of the NLC alone was three times that of the PR (Pervez Tahir, 2017).

(3) Preference to Road Infrastructure. On the other hand, the government spent three times more on road sector. This combination of neglect to railways and preference to roads was the root cause of downfall railways. Ministry of Railways, which was responsible for providing funds for the maintenance and development of the railway network, did not have any long-term framework for capital support or further development.

(4) Other Factors. After 1973, Pakistan Railways' budget was combined with the national budget with the result that the profit Pakistan Railways earned was diverted to other heads, leaving less space for its maintenance, expansion, and improvement. The other reasons for the decline of were decrease in assets like locomotives, wagons, and track kilometers. Maximum of assets including the physical infrastructure, rolling stock, passenger and freight wagons have lived their productive lives. The poor physical infrastructure not only interrupted the efficiency of services provided by railways but also increased the probability of unexpected events such as rail calamities.

At the initial stage, complete deficit of transport infrastructure in the country gave full opportunities to railway industry to fill the gap and it transported millions of people and goods; however, with the passage of time, road network improved and private transport sector started providing better alternatives for travel in even remote areas of the country. Railways gradually lost their business after shift of passenger and goods transportation to other modes like buses, wagons, and truck services.

4.2. The Second Round of Industrial Life Cycle of Pakistan Railways (1999-2011). Pakistan Railways experienced a second round of industrial life cycle from 1999 to 2011 . The level of railway development was on the rise from year 1999 to 2005, but the pace of development was slow and the level of railway development was experiencing a downward trend from 2005 to 2011 .

4.3. The Third Round of Life Cycle of the Railway Industry (2011-Present). From the year 2011, the upward trend of combined utility curve shows a new round of industry life cycle of railway industry by increase in number of passengers and freights carried. Pakistan Railways has acquired new locomotives, wagons, and number of passengers and tonnes of freight have increased. To revive Pakistan Railways, the current government has proposed Pakistan Railways Vision 2025. It is expected that railways share in transportation will be increased from $4 \%$ to $20 \%$ by 2025 [39].

4.3.1. China-Pakistan Economic Corridor (CPEC). In line with the government's Vision 2025 for infrastructure development, Pakistan Railways is to undertake necessary steps to increase its share in the overall transport sector of Pakistan during the next 10 years. A priority project in this regard is China-Pakistan Economic Corridor (CPEC) and upgradation of ML-1 route that connects Karachi, Lahore, and Peshawar (main cities of Pakistan). China and Pakistan have signed memorandum of understanding (MoU) to increase the speed of the railway connecting Karachi and Peshawar as well as to upgrade its signal system and railway stations $[40,41]$. This also includes efforts of doubling the train tracks to control traffic. Doubling of track from Khanewal to Raiwind is near to complete. Provision of signaling system on Lodhran-Khanpur-Kotri section and centralized traffic control are also underway.

4.3.2. Modernization of Infrastructure. Pakistan will receive a total of 55 modern locomotives from USA. A consignment of seven locomotives reached Pakistan from the United States to reinforce Pakistan Railways' existing fleet and the remaining 48 are expected to be handed over to Pakistan Railways by the end of 2017. The modern locomotives are designed for a maximum speed of $120 \mathrm{~km}$ per hour and are expected to provide better fuel efficiency and longer maintenance intervals $[40,41]$. Currently, the fastest speed trains can achieve is $105 \mathrm{~km} / \mathrm{h}$ only, where tracks are in good condition. The target for current management is to take this up to $160 \mathrm{~km} / \mathrm{h}$. Pakistan Railways has also undertaken renovation of several railways stations and also plans to strengthen and rehabilitate 159 weak bridges by June 2017 [42].

4.3.3. Improvement in Services and Performance. Over the period of the past two years, Pakistan Railways has managed to achieve a punctuality rate of $70 \%$ in 2015 , in comparison to $53 \%$ in 2013 [42]. This is a marked improvement when compared to $70 \%$ punctuality rate in India and $87 \%$ punctuality rate in UK. Seemingly improved services and comforts offered to passengers are one of the reasons contributing towards the increase in number of passengers and freights carried. Pakistan Railways claims that the improved services include improved food quality, water dispensers, and Wi-Fi facilities.

\section{Conclusion}

This paper examined the rise and fall of Pakistan railways industry using industry life cycle and principal component analysis from year 1950 to 2014. Data were collected from Pakistan Railway Year Book 2014-15 and SPSS software was used for statistical analysis. Principal component analysis was used to calculate the eigenvalues and contribution rates of the common factors and seven indicators, passenger volume, 
average passenger mileage, passenger turnover, freight volume, average freight mileage, freight turnover, and number of employed persons, were included for the analysis.

The results represented that Pakistan railways experienced the first round of industrial life cycle from 1950 to 1999 and completed four stages of introduction, growth, maturity, and decline. Pakistan railways story is a dramatic history of rise and decline. At the beginning of railway industry, its prominent feature was the lack of railway infrastructure, most needed to be reconstructed and repaired, but with the passage of time rail transport had greatly improved. After 1955, the rail industry had made considerable progress in expanding railway network and improved the quality of service to passengers and freight by new equipment and technology, management innovation, and increase in transport capacity. Railway business was at the peak between mid-sixties and early seventies.

The level of railways started to decline after 1975 and it was at its minimum level in the year 1999. Role of Pakistan Railways as a catalyst for economic development has received a setback due to significant underinvestment by successive governments that preferred investment in road infrastructure at the cost of railways and also developed other organizations in the same sector, that is, NLC.

Pakistan railways experienced a new round of industry life cycle after the year 2011 by increase in number of passengers and freights carried. To revive the fame of Pakistan Railways, the current government has developed a vision paper named "Vision 2025." The vision document aims to improve (including improved quality services) the share in transportation sector from $4 \%$ to $20 \%$ by 2025 , which seems to be an onerous challenge for the organization.

\section{Conflicts of Interest}

The authors declare that there are no conflicts of interest regarding the publication of this paper.

\section{Acknowledgments}

This research was supported by Fundamental Funds for Humanities and Social Sciences of Beijing Jiaotong University (B16JB00200).

\section{References}

[1] H. Stripple and S. Uppenberg, "Life Cycle Assessment of Railways and Rail Transports," 2010.

[2] S. M. Irfan, D. M. H. Kee, and S. Shahbaz, "Service quality and rail transport in Pakistan: a passenger perspective," World Applied Sciences Journal, vol. 18, no. 3, pp. 361-369, 2012.

[3] CER and UIC, "Rail Transportation and Environment: Facts \& Figures," 2015.

[4] W. L. Hill Charles and R. Gareth, Industry Life-Cycle Analysis. Strategic Management: An Integrated Approach, CengageBrain.com, 2012.

[5] E. V. Karniouchina, S. J. Carson, J. C. Short, and D. J. Ketchen Jr., "Extending the firm vs. industry debate: Does industry life cycle stage matter?" Strategic Management Journal, vol. 34, no. 8, pp. 1010-1018, 2013.

[6] W. J. Abernathy, Mastering the Dynamics of Innovation, Harvard Business School Press, Boston, MA, USA, 1994.

[7] J. M. Utterback and F. F. Suárez, "Innovation, competition, and industry structure," Research Policy, vol. 22, no. 1, pp. 1-21, 1993.

[8] S. Klepper, "Industry life cycles," Industrial and Corporate Change, vol. 6, no. 1, pp. 145-181, 1997.

[9] R. Adner and D. Levinthal, "Demand heterogeneity and technology evolution: implications for product and process innovation," Management Science, vol. 47, no. 5, pp. 611-628, 2001.

[10] P. Michael, Competitive Strategy: Techniques for Analyzing Industries and Competitors, The Free Press, 1980.

[11] W. J. Abernathy and J. M. Utterback, "How Industries Change," MIT Technology Review, vol. 80, no. 7, pp. 40-47, 1978.

[12] A. M. McGahan, "How industries change," Harvard Business Review, vol. 82, no. 10, pp. 86-94, 2004.

[13] J. M. Campa and K. Simi, "Explaining the diversification discount," Journal of Finance, vol. 57, no. 4, pp. 1731-1762, 2002.

[14] V. Maksimovic and G. Phillips, "Do conglomerate firms allocate resources inefficiently across industries?" Journal of Finance, vol. 57, no. 2, pp. 1731-1762, 2003.

[15] B. Villalonga, "Diversification discount or premium? new evidence from the business information tracking series," Journal of Finance, vol. 59, no. 2, pp. 479-506, 2004.

[16] Z. Tomes, Long-Term Structural Decline of Railways, Masaryk University, 2006.

[17] A. Sabol, M. Šander, and Đ. Fučkan, "The concept of industry life cycle and development of business strategies," in Proceedings of the Management, Knowledge and Learning International Conference, pp. 635-42, 2013.

[18] M. Cusumano, S. Kahl, and F. Suarez, "Product, process, and service: a new industry lifecycle model," A research and education initiative at the MIT Sloan School of Management, Working Paper, 2006, pp. 1-39.

[19] N. Argyres and L. Bigelow, "Does transaction misalignment matter for firm survival at all stages of the industry life cycle?" Management Science, vol. 53, no. 8, pp. 1332-1344, 2007.

[20] A. Macdonald and C. M. Hartt, "A strategic industry life cycle analysis for nova scotia's new world wines," American International Journal of Social Science, vol. 3, no. 7, pp. 117-132, 2014.

[21] G. L. Urban, T. Carter, S. Gaskin, and Z. Mucha, "Market share rewards to pioneering brands: an empirical analysis and strategic implications," Management Science, vol. 32, no. 6, pp. 645-659, 1986.

[22] R. A. Kerin, P. R. Varadarajan, and R. A. Peterson, "First-mover advantage: a synthesis, conceptual framework, and research propositions," Journal of Marketing, vol. 56, no. 4, pp. 33-52, 1992.

[23] Đ. Kalicanin, "Extending the firm vs. industry debate: does industry life cycle stage matter?" Strategic Management Journal, vol. 15, no. 177, pp. 89-102, 2008.

[24] M. B. Lieberman and D. B. Montgomery, "First-mover (dis)advantages: Retrospective and link with the resource-based view," Strategic Management Journal, vol. 19, no. 12, pp. 1111-1125, 1998.

[25] P. N. Bloom and K. Philip, "Strategies for High Market-Share Companies," Harvard Business Review, vol. 53, no. 6, pp. 63-72, 1975. 
[26] X. Li and W. Yan, "Analysis on the development trend of China railway based on industry life cycle theory," China Railway Science, vol. 32, no. 1, pp. 127-132, 2011.

[27] G. T. Lumpkin and G. G. Dess, "Linking two dimensions of entrepreneurial orientation to firm performance: The moderating role of environment and industry life cycle," Journal of Business Venturing, vol. 16, no. 5, pp. 429-451, 2001.

[28] D. B. Audretsch and M. P. Feldman, "Innovative clusters and the industry life cycle," Review of Industrial Organization, vol. 11, no. 2, pp. 253-273, 1996.

[29] Railway Year Book, "Ministry of Railways Pakistan," 2014, http:// iqbalkalmati.blogspot.hk/2016/03/pakistan-railways-year-book2014-15-in.html.

[30] Springer, Principal Component Analysis, Springer Series in Statistics, Springer, New York, NY, USA, 2nd edition, 2002.

[31] S. Raschka, "Principal Component Analysis in 3 Simple Steps," 2016.

[32] R. L. Gorsuch, Factor Analysis, LEA, Hillsdale, NJ, USA, 2nd edition, 1983.

[33] I. Smith Lindsay, "A tutorial on principal components analysis introduction," Cornell University, USA, vol. 51, no. 52, p. 65 , 2002.

[34] J. Khan, J. S. Wei, M. Ringnér et al., "Classification and diagnostic prediction of cancers using gene expression profiling and artificial neural networks," Nature Medicine, vol. 7, no. 6, pp. 673-679, 2001.

[35] J. Landgrebe, W. Wurst, and G. Welzl, "Permutation-validated principal components analysis of microarray data," Genome Biology, vol. 3, no. 4, pp. 1-19, 2002.

[36] Q. Wang and X. Wang, "Assessment of agricultural modernization level in Zhejiang using SPSS software," in Proceedings of the The 5th International Conference on Computer Science Education (ICCSE), pp. 1069-1073, Hefei, China, August 2010.

[37] R. Beaumont, "An Introduction to Principal Component Analysis Factor Analysis Using SPSS 19 and R (Psych Package)," Journal of Geophysical Research: Atmospheres, 2012.

[38] K. Khaleeq, "Poor Infrastructure a Major Hurdle to Growth," 2013, Dawn News, https://www.dawn.com/news/1044734.

[39] Pakistan 2025 One Nation-One Vision, "Ministry of Planning, Development \& Reform, Government of Pakistan,” 2015.

[40] The Express Tribune, "China, Pakistan to Upgrade 1,600kms of Railway Lines," 2017.

[41] The Express Tribune, "Consignment of Modern US Locomotives Reaches Karachi," The Express Tribune, 2017.

[42] Pakistan Institue of Legislative Development And Transparency, Pakistan Railways: A Performance Analysis, 2015. 


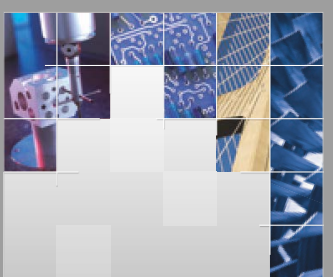

\section{Enfincering}
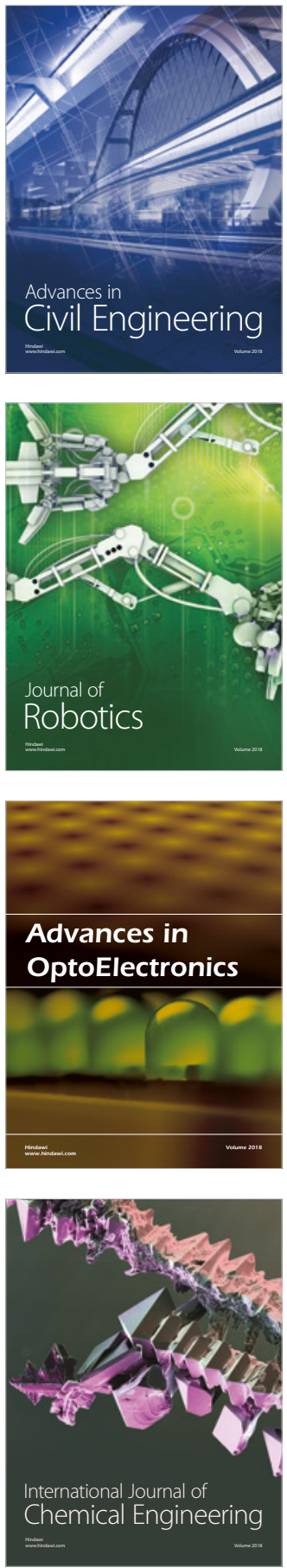

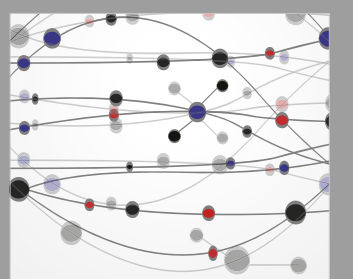

\section{Rotating \\ Machinery}

The Scientific World Journal

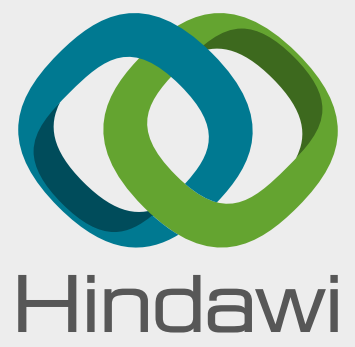

Submit your manuscripts at

www.hindawi.com
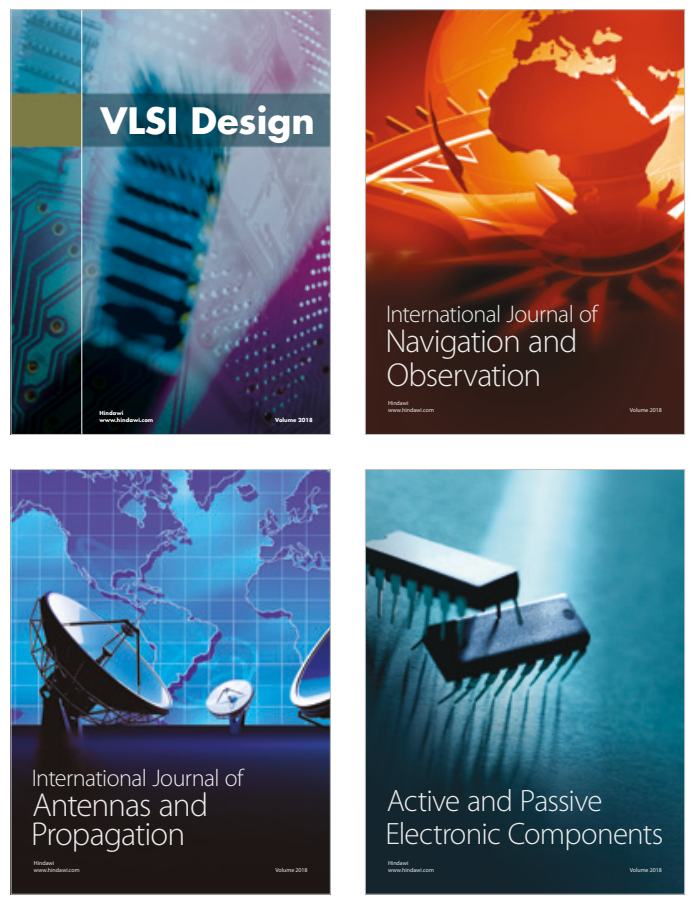
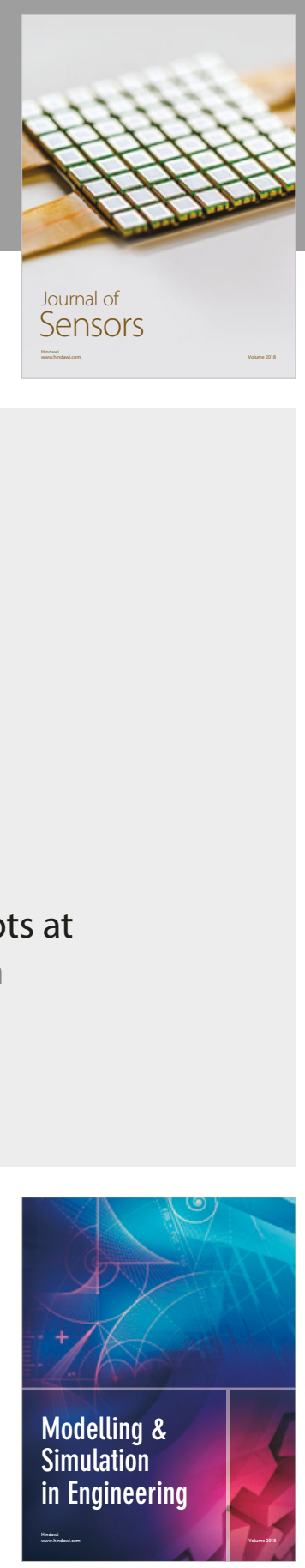

\section{Advances \\ Multimedia}
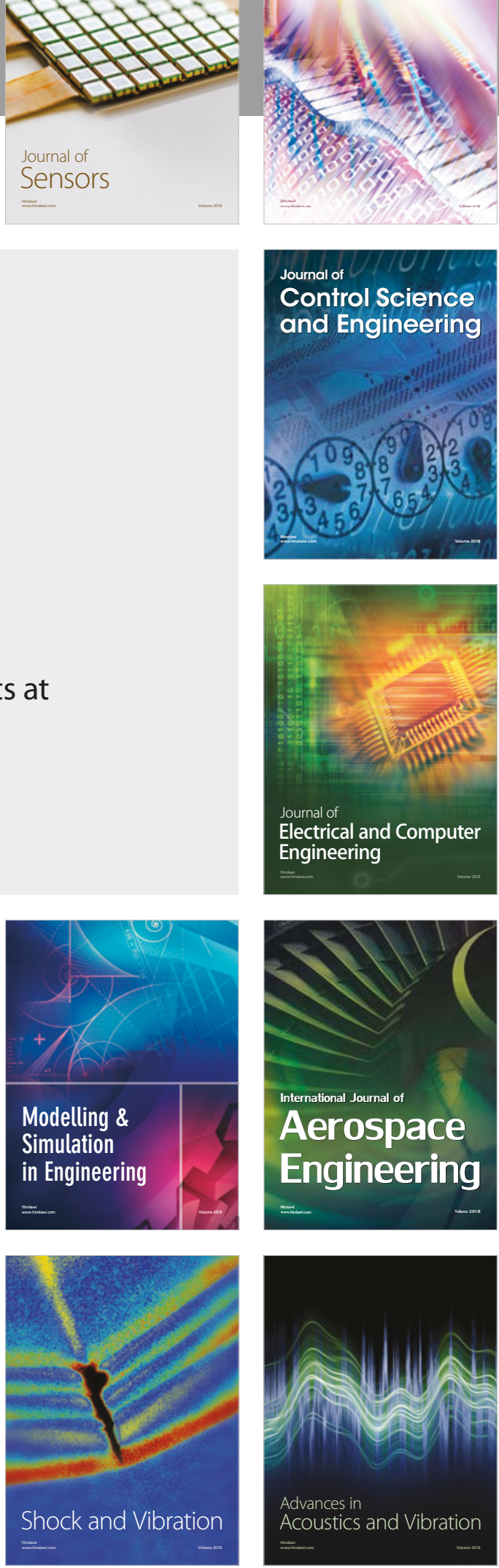